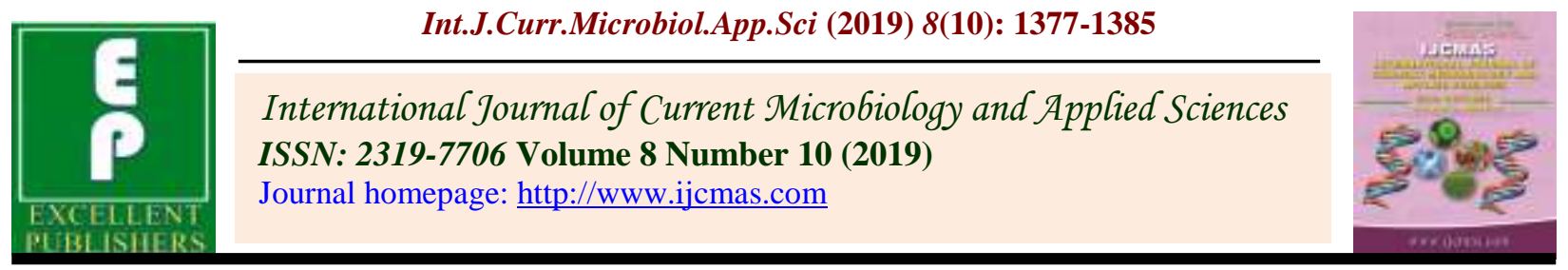

\title{
Effect of Inorganic and Biofertilizers on Growth of Gynodioecious Papaya
}

\author{
Mahendra Jadia*, S. S. Singh, S. P. Mishra, Krapal Singh Verma and Anil Kumar Patle \\ Department of Horticulture, Mahatma Gandhi Chitrakoot Gramodaya Vishwa Vidyalaya, \\ Chitrakoot, District Satna, Madhya Pradesh, India \\ *Corresponding author
}

\section{A B S T R A C T}

\begin{tabular}{|l|}
\hline K e y w o r d s \\
Inorganic, \\
Biofertilizers, \\
RDF, Papaya \\
\hline Article Info \\
\hline $\begin{array}{l}\text { Accepted: } \\
\text { 12 September } 2019 \\
\text { Available Online: } \\
\text { 10 October } 2019\end{array}$ \\
\hline
\end{tabular}

The experiment was carried out to find out the Effect of inorganic and biofertilizers on growth of Gynodioecious papaya. The treatment combinations involving ten levels of $\mathrm{T}^{-1}$ Recommended dose of NPK (RDF) i.e. 250: 250:250 g/plant/year, $\mathrm{T}^{-2} 100 \% \mathrm{RDF}+$ PSB (50g/plant), $\mathrm{T}^{-3} 100 \% \mathrm{RDF}+$ Azospirillum (50g/plant), $\mathrm{T}^{-4} 100 \% \mathrm{RDF}+$ Azotobactor (50g/plant), $\mathrm{T}^{-5} 75 \% \mathrm{RDF}+\mathrm{PSB}$ (50g/plant) + Azospirillum (50g/plant), $\mathrm{T}^{-6} 75 \% \mathrm{RDF}+\mathrm{PSB}(50 \mathrm{~g} / \mathrm{plant})+$ Azotobactor (50g/plant), $\mathrm{T}^{-7} 75 \% \mathrm{RDF}+\mathrm{PSB}$ (50g/plant) + Azospirillum (50g/plant) + Azotobactor (50g/plant), $\mathrm{T}^{-8} 50 \% \mathrm{RDF}+\mathrm{PSB}$ (50g/plant) + Azotobactor (50g/plant), $\mathrm{T}^{-9} 50 \% \mathrm{RDF}+\mathrm{PSB}(50 \mathrm{~g} / \mathrm{plant})+$ Azospirillum (50g/plant) + Azotobactor (50g/plant), $\mathrm{T}^{-10}$ Farmer's Practices were given in Red Lady variety. Maximum Plant height $(\mathrm{cm})$, Girth of stem $(\mathrm{cm})$, No of leaves per plant $(\mathrm{cm})$, Petiole length $(\mathrm{cm})$, Petiole girth $(\mathrm{cm})$, Leaf area $(\mathrm{m} 2)$, Chlorophyll content $(\mathrm{mg} / 100 \mathrm{~g}$ tissue), East-West Spread (cm),North-South spread $(\mathrm{cm})$, Days taken for $1^{\text {st }}$ flower emergence, Days taken for $1^{\text {st }}$ fruit initiation, First bearing height $(\mathrm{cm})$, Girth at bearing height $(\mathrm{cm})$, Number of leaves at first bearing height $(\mathrm{cm})$. Were observed by the maximum at 180,270 and $360 \mathrm{DAT}$ were observed under the treatment $\mathrm{T}_{7^{-}}$ $75 \% \mathrm{RDF}+\mathrm{PSB}(50 \mathrm{~g} / \mathrm{plant})+$ Azospirillumn $(50 \mathrm{~g} / \mathrm{plant})+$ Azotobactor (50g/plant) at all the growth stages.

\section{Introduction}

Papaya (Carica papaya L) is a fruit found ample in tropical and sub-tropical regions. In India it is commonly known as Papita, pawpawa or True Melon. Papaya's country of origin is South American country Mexico. From there it reached other parts of the world. Now this crop is cultivated in Australia,
Hawaii, Brazil, Malaysia, Burma, Philippines, Sri Lanka, India, South Africa, Thailand, Tropical America and all other tropical and sub-tropical countries. According to the data made available by NHB 2017, due to ideal climatic conditions in Andhra Pradesh the production of Papaya is excellent. However, in India Papaya is produced successfully all over the country round the year. According to the 
data available for the agricultural cycle year 2016-17 in India, around 136.1 thousand hectares of area is cultivated with Papaya which is around $2.10 \%$ of total fruit area production. On an average nearly 6500 MT per year of Papaya is yielded which is $6.57 \%$ of total fruit production in India. In Madhya Pradesh Papaya is cultivated on estimated area of 10.45 hectares. Productivity of Papaya in Madhya Pradesh is around 44.9 MT per hectare. If proper management is done nearly 70 to 80 tonnes per hectare of Papaya can be produced. The fruits of excellent quality are produced under mild subtropical climates where as a dry warm sunny climate tends to add the sweetness to the fruit. Cultivation of Papaya is easy and gives easy returns. The plant of Papaya has adaptability in diverse soil. Fruit of Papaya is attractive, delicious and has multifarious uses. Papaya is a very wholesome fruit. It is one of the best sources of vitamin A. Usually it is assumed that a fruit has yellow pigment due to Carotene in it but Papaya has yellow pigment because of caricaxanthin. Papaya fruit also have BCryptoxanthin $(8.1 \mu \mathrm{g} / \mathrm{g})$ representing $62 \%$ of carotenoid content causing yellow/orange fleshed cultivars which are common. Papaya fruit also has red fleshed cultivars which are due to Lycopene. Organic manures and bioinoculants are substitute of inorganic fertilizers. When these organic manures and bio-inoculants are used in the field where Papaya plant is grown the faster development of plant is clearly visible. The use of organic fertilizers and bio-inoculants increases crop productivity and also improves soil properties. The organic matter in the soil is increased. Water holding property of the soil is improved and nutrients in the soil increases thus increasing the nutritional value of Papaya fruit.The importance of organic manure and bio-fertilizers in Indian agriculture has been known since ancient times as it augments part of N, P, K and also fairly a good amount of micronutrients apart from increasing availability of applied and native soil nutrients. The practice also improves the soil quality, texture, structure, porosity, infiltration rate, aeration, flora and fauna and better root growth which have beneficial effects on crops by improving their yield, quality and postharvest traits.

\section{Materials and Methods}

A field experiment on different inorganic, biofertilizers techniques on growth Papaya (Carica papaya L.) was carried out during 2016 and 2017 at Mahatma Gandhi Chitrakoot Gramodaya Vishwa Vidyalaya, Chitrakoot, District Satna (M.P.). The research work was conducted in the Randomized Block Design with three replications. Each replication was comprised of 10 treatment combinations. In $\mathrm{T}^{-}$ ${ }^{1}$ Recommended dose of NPK (RDF) i.e. 250: 250:250 g/plant/year, $\mathrm{T}^{-2} 100 \% \mathrm{RDF}+\mathrm{PSB}$ (50g/plant), $\mathrm{T}^{-3} 100 \% \mathrm{RDF}+$ Azospirillum (50g/plant), $\mathrm{T}^{-4} 100 \% \mathrm{RDF}+$ Azotobactor (50g/plant), $\mathrm{T}^{-5} 75 \% \mathrm{RDF}+$ PSB (50g/plant) + Azospirillum (50g/plant), $\mathrm{T}^{-6} 75 \% \mathrm{RDF}+\mathrm{PSB}$ (50g/plant) + Azotobactor (50g/plant), $\mathrm{T}^{-7} 75 \%$ $\mathrm{RDF}+\mathrm{PSB}$ (50g/plant) + Azospirillum (50g/plant) + Azotobactor (50g/plant), $\mathrm{T}^{-8}$ $50 \% \mathrm{RDF}+\mathrm{PSB}(50 \mathrm{~g} / \mathrm{plant})+$ Azotobactor (50g/plant), $\mathrm{T}^{-9} 50 \% \mathrm{RDF}+\mathrm{PSB}(50 \mathrm{~g} / \mathrm{plant})+$ Azospirillum (50g/plant) + Azotobactor (50g/plant), $\mathrm{T}^{-10}$ Farmer's Practices. The Chitrakoot is situated in semi-arid and subtropical zone of Kymore Plateau \& Satpuda Hills of Madhya Pradesh, North of $24^{\circ} 31^{\prime}$ latitude and East of $81^{\circ} 15^{\prime}$ longitude with an altitude of $306 \mathrm{~m}$ from mean sea level. The soil of the investigation field was clay loam with good drainage and uniform texture with medium NPK status. Observations were recorded according to standard procedure on Plant height $(\mathrm{cm})$, Girth of stem $(\mathrm{cm})$, No of leaves per plant $(\mathrm{cm})$,Petiole length $(\mathrm{cm})$, Petiole girth $(\mathrm{cm})$, Leaf area (m2), Chlorophyll content $(\mathrm{mg} / 100 \mathrm{~g}$ tissue), EastWest Spread $(\mathrm{cm})$, North-South spread $(\mathrm{cm})$, 
Days taken for $1^{\text {st }}$ flower emergence, Days taken for $1^{\text {st }}$ fruit initiation, First bearing height $(\mathrm{cm})$, Girth at bearing height $(\mathrm{cm})$, Number of leaves at first bearing height $(\mathrm{cm})$.

\section{Results and Discussion}

\section{Vegetative growth (Table 1-3)}

The maximum plant height of plant at 180 , 270 and 360 DAT in both the years was found under the treatment $\mathrm{T} 7-75 \% \mathrm{RDF}+\mathrm{PSB}$ (50g/plant) + Azospirillumn (50g/plant) + Azotobactor (50g/plant) and minimum value was found under T10- Farmer's Practices, these results conformity with the statements "It is known fact that nitrogen is essential for cell division and cell enlargement as it increases the rotoplasm. Application of RDF + $\mathrm{PSB}+$ Azospirillum produces better results in plant height with other treatments which may be due to enhanced availability of nitrogen and phosphorus under bio fertilizer treated plots. This view was also confirmed by Suresh and Hassan (1998) and according to them inoculation with Azospirillumsaved 50 per cent of the nitrogen dose in banana. The results are also in agreement with the findings of Tripathy (2002) who reported that $50 \mathrm{~kg}$ P20S ha-1 could be saved by the use of PSB in chickpea".

Maximum girth of stem at 180, 270 and 360 DAT in both the years was observed under the treatment T7 - 75\% RDF + PSB (50g/plant) + Azospirillumn (50g/plant) +Azotobactor (50g/plant), while the minimum value was found under T10- Farmer's Practices. The increase in trunk girth may be due to improvement of physical properties of soil, higher nutrient uptake and increased activity of microorganisms which were manifested in the form of boosting growth and production of higher carbohydrates (Yadav et al., 2011a). And, it could be due to regularly supply of available nutrient from organic and inorganic form and effect of bio active substance produced by common use of bio fertilizers. Organic manures along with biofertilizers also enhanced the aeration in the soil which finally might have enhanced the physiological activities inside the plant like plant height.

The similar result was observed by Tandel et al., (2014), Shivakumar (2010), Suresh et al., (2010) and Singh et al., (2010) in papaya. Secondly things the increase in vegetative growth with increasing levels of nitrogen was because nitrogen is an important constituent of chlorophyll and amino acids. Similar observation has been reported by Jayasundara and Huruggamuwa (2005) and Akinyemi and Akande (2008).

The maximum no of leaves per plant at 180, 270 and 360 DAT in both the years was observed under the treatment T7 - 75\% RDF + PSB (50g/plant) + Azospirillumn (50g/plant) + Azotobactor (50g/plant), while the minimum no of leaves per plant was found under T10Farmer's Practices. Increased number of leaves per plant might have produced more photosynthates in plants. It is evident that organic sources of nutrients have beneficial effect on growth and development of papaya (Babu et al., 1989). Addition of organic manures to the soil in conjunction with chemical fertilizers and bioinoculants increases the availability of nutrients on long term basis, resulting in favorable effect on plant growth. Amiri et al., 2008 and Amiri et al., 2010 reported about the probiotic effect of microbial inoculants (viz; Trichoderma, Mycoplex and Mycorrhiza roots) in improving the plant growth parameters at the seedling stage in papaya. Increase in the vegetative growth may be either due to better root growth and root spread or improved nutrient availability to plants. Maximum petiole length at 180, 270 and 360 DAT for pooled analysis basis was observed under the treatment $\mathrm{T} 7$ $75 \%$ RDF + PSB (50g/plant) + Azospirillumn 
(50g/plant) + Azotobactor $(50 \mathrm{~g} /$ plant $)$, while the minimum petiole length was found under T10- Farmer's Practices. Sharma 2004, confirm the findings on petiole length followed a similar trend, This increase might be due to the availability of major as well minor nutrient elements at optimum proportion in the soil and assimilation of food material within the plant. The duration and petiole length was minimum under farmers' practices.

Maximum petiole girth at 180, 270 and 360 DAT in both the years for pooled analysis basis was observed under the treatment T7 $75 \% \mathrm{RDF}+\mathrm{PSB}$ (50g/plant)+Azospirillumn (50g/plant) + Azotobactor (50g/plant), while the minimum petiole girth was found under T10- Farmer's Practices.

Maximum leaf area at 180, 270 and 360 DAT for pooled analysis basis was observed under the treatment $\mathrm{T} 7-75 \% \mathrm{RDF}+\mathrm{PSB}$ (50g/plant) + Azospirillumn (50g/plant) + Azotobactor (50g/plant), while the minimum leaf area was found under T10- Farmer's Practices. The lowest leaf area was observed under farmers' practices at all the stages of plant growth. The higher leaf area under T7$75 \% \mathrm{RDF}+\mathrm{PSB}$ (50g/plant) + Azospirillumn (50g/plant) + Azotobactor (50g/plant) might be due to availability of full dose of recommended nitrogen and additional source of nitrogen through biofertilizers. It is well defined that nitrogen increases the chlorophyll synthesis resulting in more area for photosynthesis and net assimilation (Bhukta, 2000).

Maximum chlorophyll content at 180, 270 and 360 DAT for pooled analysis basis was observed under the treatment T7 - 75\% RDF + PSB (50g/plant) + Azospirillumn (50g/plant) + Azotobactor (50g/plant), while the minimum chlorophyll content was found under T10Farmer's Practices. The papaya plants treated with combined application of inorganic fertilizer and bio fertilizers treatment. Inorganic fertilizer had significantly boost the physiological parameters and resulted into higher production of photosynthates, translocation of water, nutrient and photosynthates resulting into rapid cell division. The bio fertilizers are play key role in utilization of nutrients in the soil like bio compost, vermi compost, caster cake with inorganic fertilizer are more efficient in maintaining a better photosynthetic efficiency, which is responsible to maintain a better physiological status of the plant. Higher photosynthetic activity is a good indication of physiologically efficient plants in banana.

This primarily depends upon the chlorophyll content of leaf. The chlorophyll content in leaves indicates the efficiency of photosynthesis, where the solar energy is converted into chemical energy. N, P and K were utilized efficiently by the plant, which resulted in producing maximum photosynthates in terms of high biomass and translocating the assimilated materials to the developing sink. The role of nitrogen and potassium in the functioning of chlorophyll is well established.

These results are in accordance with results reported by Kuttimani et al., (2013). In general, treated plants registered more photosynthetic rate and transpiration. Plant photosynthesis appears complex concentration profiles influenced by many factors. According to Sharkey and Ogawa (1987) it has very close relation to photosynthesis, transpiration and respiration. In the present investigation increased rate of photosynthesis is associated with increased transpiration rate with maximum leaf temperature. The similar result was observed by Jeyakumar et al., (2001) in papaya and Ghumare (2009) in sapota. 
Table.1 Effect of inorganic and bio-fertilizers on vegetative growth of Papaya

\begin{tabular}{|c|c|c|c|c|c|c|c|c|c|}
\hline \multirow[t]{2}{*}{ Treatments } & \multicolumn{3}{|c|}{ Plant height (cm) } & \multicolumn{3}{|c|}{ Girth of stem (cm) } & \multicolumn{3}{|c|}{ No of leaves per plant (cm) } \\
\hline & 180 DAT & 270 DAT & 360 DAT & 180 DAT & 270 DAT & 360 DAT & 180 DAT & 270 DAT & 360 DAT \\
\hline $\mathbf{T}_{1}$ & 122.92 & 169.24 & 175.29 & 26.84 & 41.06 & 45.06 & 21.88 & 31.21 & 40.88 \\
\hline $\mathbf{T}_{2}$ & 125.17 & 173.81 & 182.26 & 29.84 & 43.72 & 48.53 & 25.02 & 34.32 & 44.33 \\
\hline $\mathbf{T}_{3}$ & 124.84 & 172.00 & 183.09 & 29.01 & 42.94 & 47.87 & 23.36 & 32.78 & 42.80 \\
\hline $\mathbf{T}_{4}$ & 125.65 & 171.27 & 183.44 & 27.71 & 42.92 & 46.45 & 22.11 & 31.44 & 41.60 \\
\hline $\mathbf{T}_{5}$ & 120.16 & 160.25 & 171.41 & 23.97 & 34.49 & 43.81 & 21.82 & 31.83 & 41.60 \\
\hline $\mathbf{T}_{6}$ & 119.86 & 161.16 & 169.29 & 23.93 & 37.38 & 43.19 & 20.65 & 30.95 & 40.96 \\
\hline $\mathbf{T}_{7}$ & 131.46 & 178.23 & 185.94 & 30.45 & 44.55 & 50.76 & 25.19 & 34.58 & 44.93 \\
\hline $\mathbf{T}_{8}$ & 112.45 & 157.94 & 170.77 & 22.89 & 36.05 & 41.41 & 19.02 & 28.44 & 40.17 \\
\hline $\mathbf{T}_{9}$ & 112.39 & 157.97 & 169.57 & 22.81 & 35.41 & 40.75 & 18.65 & 28.31 & 38.73 \\
\hline $\mathrm{T}_{10}$ & 106.19 & 150.10 & 158.32 & 20.21 & 34.07 & 39.97 & 18.46 & 27.44 & 38.35 \\
\hline 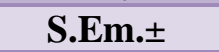 & 0.1593 & 0.2021 & 0.187 & 0.0711 & 0.0944 & 0.0735 & 0.0502 & 0.0504 & 0.0453 \\
\hline CD at $5 \%$ & 0.4569 & 0.5796 & 0.538 & 0.2038 & 0.2709 & 0.2109 & 0.1440 & 0.1446 & 0.1299 \\
\hline
\end{tabular}

Table.2 Effect of inorganic and bio-fertilizers on vegetative growth of Papaya

\begin{tabular}{|c|c|c|c|c|c|c|c|c|c|}
\hline \multirow[t]{2}{*}{ Treatments } & \multicolumn{3}{|c|}{ Petiole length $(\mathrm{cm})$} & \multicolumn{3}{|c|}{ Petiole girth $(\mathrm{cm})$} & \multicolumn{3}{|c|}{ Leaf area $\left(\mathrm{m}^{2}\right)$} \\
\hline & 180 DAT & 270 DAT & 360 DAT & 180 DAT & 270 DAT & 360 DAT & 180 DAT & 270 DAT & 360 DAT \\
\hline $\mathbf{T}_{1}$ & 24.06 & 33.56 & 40.55 & 8.65 & 8.68 & 8.97 & 4.74 & 7.06 & 9.12 \\
\hline $\mathbf{T}_{2}$ & 25.26 & 34.36 & 41.36 & 9.46 & 9.86 & 9.92 & 5.19 & 7.84 & 10.00 \\
\hline $\mathbf{T}_{3}$ & 25.13 & 34.14 & 41.13 & 9.25 & 9.28 & 9.33 & 4.45 & 7.34 & 9.62 \\
\hline $\mathbf{T}_{4}$ & 24.83 & 33.85 & 40.84 & 8.72 & 8.73 & 8.94 & 4.73 & 7.13 & 9.33 \\
\hline $\mathbf{T}_{5}$ & 23.76 & 32.78 & 39.77 & 8.62 & 8.64 & 8.75 & 4.62 & 6.95 & 8.95 \\
\hline $\mathbf{T}_{6}$ & 22.96 & 32.47 & 39.47 & 8.45 & 8.49 & 9.17 & 4.54 & 6.83 & 8.87 \\
\hline $\mathbf{T}_{7}$ & 25.96 & 36.47 & 43.46 & 9.64 & 9.87 & 10.04 & 5.22 & 7.97 & 10.20 \\
\hline $\mathbf{T}_{8}$ & 23.01 & 31.71 & 39.01 & 8.32 & 8.34 & 8.44 & 4.38 & 6.11 & 7.82 \\
\hline $\mathbf{T}_{9}$ & 22.76 & 31.77 & 38.77 & 8.15 & 8.17 & 8.21 & 4.24 & 5.97 & 7.36 \\
\hline$T_{10}$ & 22.07 & 31.08 & 38.08 & 7.61 & 7.90 & 8.01 & 3.85 & 5.19 & 6.69 \\
\hline S.Em. \pm & 0.0282 & 0.0331 & 0.0325 & 0.0128 & 0.0138 & 0.014 & 0.0089 & 0.0177 & 0.0236 \\
\hline CD at $5 \%$ & 0.0810 & 0.0950 & 0.0932 & 0.0366 & 0.0395 & 0.041 & 0.0255 & 0.0507 & 0.0677 \\
\hline
\end{tabular}


Table.3 Effect of inorganic and bio-fertilizers on vegetative growth of Papaya

\begin{tabular}{|c|c|c|c|c|c|c|c|c|c|}
\hline \multirow[t]{2}{*}{ Treatments } & \multicolumn{3}{|c|}{ Chlorophyll content (mg/100g tissue) } & \multicolumn{3}{|c|}{ East-West Spread (cm) } & \multicolumn{3}{|c|}{ North-South spread (cm) } \\
\hline & 180 DAT & 270 DAT & 360 DAT & 180 DAT & 270 DAT & 360 DAT & 180 DAT & 270 DAT & $360 \mathrm{DAT}$ \\
\hline $\mathbf{T}_{1}$ & 132.89 & 131.37 & 130.25 & 145.54 & 164.03 & 173.03 & 127.79 & 171.36 & 177.59 \\
\hline $\mathbf{T}_{2}$ & 139.69 & 138.17 & 137.05 & 163.44 & 183.74 & 192.74 & 157.77 & 180.17 & 189.17 \\
\hline $\mathbf{T}_{3}$ & 136.59 & 135.02 & 133.89 & 154.25 & 174.82 & 183.82 & 151.53 & 178.95 & 187.95 \\
\hline $\mathbf{T}_{4}$ & 135.99 & 134.42 & 133.29 & 149.38 & 166.29 & 177.79 & 150.28 & 175.43 & 183.02 \\
\hline $\mathbf{T}_{5}$ & 131.92 & 130.40 & 129.27 & 142.93 & 160.77 & 169.77 & 141.74 & 162.72 & 171.73 \\
\hline $\mathbf{T}_{6}$ & 123.15 & 121.63 & 120.50 & 132.51 & 147.81 & 156.81 & 134.27 & 160.16 & 169.16 \\
\hline $\mathbf{T}_{7}$ & 144.09 & 142.57 & 141.45 & 164.44 & 190.56 & 199.41 & 159.97 & 183.87 & 192.87 \\
\hline $\mathbf{T}_{8}$ & 122.63 & 121.27 & 119.86 & 131.52 & 146.64 & 156.10 & 135.44 & 151.03 & 160.03 \\
\hline $\mathbf{T}_{9}$ & 121.70 & 120.36 & 117.20 & 131.56 & 146.63 & 155.21 & 133.63 & 146.20 & 155.20 \\
\hline $\mathbf{T}_{10}$ & 114.97 & 110.95 & 109.28 & 129.17 & 143.73 & 152.73 & 129.56 & 144.60 & 153.60 \\
\hline S.Em.土 & 0.1901 & 0.1994 & 0.2062 & 0.2725 & 0.3394 & 0.3400 & 0.2678 & 0.3018 & 0.2967 \\
\hline $\mathrm{CD}$ at $5 \%$ & 0.5452 & 0.5718 & 0.5914 & 0.7816 & 0.9734 & 0.9751 & 0.7680 & 0.8657 & 0.8509 \\
\hline
\end{tabular}

Table.4 Effect of inorganic and bio-fertilizers on reproductive growth of Papaya

\begin{tabular}{|c|c|c|c|c|c|}
\hline Treatments & $\begin{array}{c}\text { Days taken for } 1^{\text {st }} \text { flower } \\
\text { emergence }\end{array}$ & $\begin{array}{l}\text { Days taken for } 1^{\text {st }} \\
\text { fruit initiation }\end{array}$ & $\begin{array}{l}\text { First bearing } \\
\text { height }(\mathbf{c m})\end{array}$ & $\begin{array}{c}\text { Girth at bearing } \\
\text { height }(\mathrm{cm})\end{array}$ & $\begin{array}{c}\text { Number of leaves at first bearing } \\
\text { height }(\mathrm{cm})\end{array}$ \\
\hline $\mathbf{T}_{1}$ & 107.62 & 138.76 & 69.10 & 5.67 & 23.19 \\
\hline $\mathbf{T}_{2}$ & 103.46 & 131.82 & 59.97 & 5.98 & 27.64 \\
\hline $\mathbf{T}_{3}$ & 105.14 & 133.99 & 64.87 & 5.87 & 25.55 \\
\hline $\mathbf{T}_{4}$ & 106.51 & 135.18 & 64.89 & 5.77 & 24.10 \\
\hline $\mathbf{T}_{5}$ & 111.14 & 139.89 & 67.93 & 5.55 & 22.58 \\
\hline $\mathbf{T}_{6}$ & 110.16 & 139.99 & 69.98 & 5.40 & 21.71 \\
\hline $\mathbf{T}_{7}$ & 102.17 & 128.40 & 59.46 & 6.91 & 29.12 \\
\hline $\mathbf{T}_{8}$ & 111.52 & 141.81 & 74.35 & 4.96 & 21.54 \\
\hline $\mathbf{T}_{9}$ & 111.89 & 141.81 & 71.54 & 4.87 & 20.56 \\
\hline$T_{10}$ & 114.89 & 145.28 & 73.69 & 4.50 & 17.71 \\
\hline S.Em.土 & 0.0849 & 0.1072 & 0.1140 & 0.0138 & 0.0698 \\
\hline CD at $5 \%$ & 0.2436 & 0.3074 & 0.3270 & 0.0396 & 0.2001 \\
\hline
\end{tabular}


Maximum East-West spread and North-South Spread at 180, 270 and 360 DAT in two years was observed under the treatment $\mathrm{T} 7-75 \%$ $\mathrm{RDF}+\mathrm{PSB}$ (50g/plant) + Azospirillumn (50g/plant) + Azotobactor $(50 \mathrm{~g} / \mathrm{plant})$, while the minimum East-West spread and NorthSouth Spread was found under T10- Farmer's Practices. It was observed that application of $75 \%$ RDF produced significantly higher plant spread and it was noted to be the highest at maturity. The highest plant spread under this treatment was mainly due to longer petiole length and maximum leaf area at this stage. In papaya, petiole length contributes maximum part of spread and it was positively influenced by this treatment. The minimum plant spread was recorded with the farmer's practices, in both directions during both the years and on pooled basis. This might be due to use of fertilizers without any other bio fertilizers dose of as well as other nutrients resulting in restricted growth and ultimately minimum plant spread (Sharma, 2004).

\section{Reproductive growth (Table 4)}

Minimum days taken for 1st flower emergence by pooled basis was observed under the treatment T7 - 75\% RDF + PSB (50g/plant) + Azospirillumn (50g/plant) + Azotobactor (50g/plant), while the maximum days taken for 1 st flower emergence was found under T10- Farmer's Practices. This results conformity with Srinu et al., 2017, the earliness in flowering might be due to the higher net assimilation rate on account of better growth leading to the production of endogenous metabolites earlier in optimum level enabling early flower reported by (Singh and Varu 2013) and (Yadav et al., 2011) in papaya, and lower days taken to maturity, which might have improved the yield parameters by better presence and uptake of nutrient by plant roots and boosting the source - sink relationship by increasing the transportation of carbohydrates from the leaves to the fruits. Similar findings have been observed by Yadav 2006, Srivastava 2008 in papaya. Early flowering could be attributed to higher availability and uptake of nitrogen, phosphorus and potassium in proper ratio (Rao and Rao, 1978 in CO 1 papaya; Purohit et al., 1979 in Coorg Honey Dew papaya; Reddy and Kohli, 1989). Shivaputra et al., (2004) also reported early reproductive phase in papaya with vermicompost + inorganic fertilizers. This was contradictory to the findings of Rajbhar et al., (2010), who suggested that lesser nutrient level enhances early flowering in papaya at a lower node.

Minimum days taken for 1st fruit initiation by pooled basis was observed under the treatment $\mathrm{T} 7$ - 75\% RDF + PSB (50g/plant) + Azospirillumn (50g/plant) + Azotobactor (50g/plant), while the maximum days taken for 1st fruit initiation was found under T10Farmer's Practices.

Minimum first bearing height by pooled basis was observed under the treatment T7 - 75\% $\mathrm{RDF}+\mathrm{PSB}$ (50g/plant) + Azospirillumn (50g/plant) + Azotobactor (50g/plant), while the maximum first bearing height was found under T10- Farmer's Practices. These results are in close corroborated with the findings of Patil et al., (1995) and Mahajan et al., (1998) who reported 10-12 days earlier bearing/maturity in various vegetable crops with the use of fermented fresh cattle dung solutions.

Flowering and bearing height were significantly influenced due to fertigation levels and blending of nutrients. The application of $75 \%$ RDF with biofertilizers recorded significantly maximum flowering and it was minimum under only farmers practices. The application of inorganic fertilizers + PSB + Azospirillum was found to be statistically best in producing bearing height under both the years as well as on 
pooled basis. Similar findings in respect of flowering and bearing height have been reported by Patil et al., (1995) and Patil et al., (1997).

Maximum girth at bearing height by pooled basis was observed under the treatment T7 $75 \% \mathrm{RDF}+\mathrm{PSB}$ (50g/plant) + Azospirillumn (50g/plant) + Azotobactor (50g/plant), while the minimum girth at bearing height was found under T10- Farmer's Practices.

Maximum number of leaves at first bearing height by pooled basis was observed under the treatment T7 - 75\% RDF + PSB (50g/plant) + Azospirillumn (50g/plant) + Azotobactor (50g/plant), while the minimum number of leaves at first bearing height was found under Farmer's Practices.

\section{References}

Akinyemi, S.O.S. and Akande, M.O. (2008). Effect of organic and inorganic fertilizers on growth and yield of papaya (Carica papaya L.). In: Kumar, N., Soorianathasundaram, K. and Jeyakumar, P. (eds.), Second International Symposium on Papaya, 912 December, TNAU, Coimbatore, India. Pp 96.

Amiri, A.W., Shyamalamma, S. and Gowda, V.N. (2008). Effect of bio-inoculants on growth and performance of papaya (cv. Solo) seedlings in the nursery. In: Kumar, N., Soorianathasundaram, K. and Jeyakumar, P. (eds.), Second International Symposium on Papaya, 912 December, TNAU, Coimbatore, India. Pp 95.

Athani, S.I., Hulamani, N.C and Shirol, A.M. (1999). Effect of vermi compost on maturity and yield of banana cv. Rajapuri (Musa AAB). South Indian Hort., 47(1-6):4-7

Bhukta, M. (2000). Integrated use of cow dung slurry or FYM with inorganic fertilizers on soil fertility, growth, yield and nutrient uptake of potato. M.Sc. Thesis, IGAU, Raipur (C.G.), pp 80-82.

Babu, R.L., Mohandas, S., Veerannah, L. and Nagarajan, M. (1989). Leaf area in relation to petiole length in papaya. $S$. Indian Hort., 26: 103-107.

Ghumare, V. S. (2009). Study of foliar spray of chemicals on flowering, yield, quality, morphophysiological parameters and leaf nutrient contents of Sapota cv. Kallipatti. M.Sc. (Hort.) Thesis submitted to NAU, Navsari, GJ India.

Jayasundara, J.M.P.B. and Huruggamuwa, H.M.N.K. (2005). Effect of organic and chemical fertilizers on growth, yield and fruit quality of papaw. Ann. Srilanka Dep. Agric., 7:103-110.

Jeyakumar, P., Durgadevi, D. and Kumar, N. (2001). Effect of zinc and boron fertilization on improving fruit yields in papaya (Carica papaya L.) cv. CO-5. Plant nutrition, Food security and sustainability of agro- ecosystems, 356357.

Kuttimani, R., Velayudham, K., Somasundararam, E. and Jagatjothi, N. (2013). Effect of integrated nutrient management on corm and root growth and physiological parameters of banana. International J. Advance Res., 1(8): 4655.

Patil, K.B., Patil, B.B. and Patil, M.T. (1995). Nutritional investigation in Papaya var. Washington. J. Maharastra Agril. Univ., 20(3): 364-366.

Patil, K.B., Patil, B.B. and Patil, M.T. (1997). Studies on manurial requirement of papaya. J. of Soils and Crops, 7(2): 123127.

Rajbhar, Y.P., Singh, G. and Lal, M. (2010). Effect of N, P, K and spacing on growth and yield of papaya (Carica papaya L.) cv. Pant Papaya-1. In: Kumar, N., Soorianathasundaram, K. and Jeyakumar, P. (Eds.), Second International Symposium on Papaya, 912 December, TNAU, Coimbatore, India, pp104.

Reddy, Y.T.N. and Kohli, R.R. (1989). Effect of 
nitrogen on growth, yield and quality in papaya (Carica papaya L.) cv. Coorg Honey Dew. Narendra Deva J. Agric. Res., 4(1):53-56.

Rao, D.V.S. and Rao, V.N.M. (1978). Effect of NPK on sex, duration and yield of CO-1 papaya (Carica papaya L.). S. Indian Hort., 26:103-107.

Singh, J.K. and Varu, D.K. (2013). Effect of integrated nutrient management in papaya (Carica papaya L.) cv. Madhubindhu. Asian J. Hortic.,8(2):667670.

Shivakumar, B. S. (2010). Integrated nutrient management studies in papaya (Carica papayaL.)cv. Surya. Ph. D. Thesis submitted to Univ. of Agril. Science, Dharwad, Karnataka.

Suresh, C.P., Nath, S., Poduval, M. and Sen, S.K. (2010). Studies on the efficacy of phosphate solubilizing microbes and VAM fungi with graded levels of phosphorus on growth, yield and nutrient uptake of papaya (Carica papaya L.). Acta Hort., 851: 401-406.

Singh, K.K., Barche, S. and Singh, D.B. (2010). Integrated nutrient management in papaya (Carica papaya L.) cv. Surya. Acta Hort., 851: 377380 .

Srivastava, A. (2008). Integrated nutrient management (Carica papaya L.). Ph.D. Thesis submitted. N.D. University of Agriculture and Technology. Faizabad (U.P.), India.

Shivaputra, S.S., Path, C.P., Swamy, G.S.K. and Patil, P.B. (2004). Cumulative effect of VAM fungi and vermin compost on nitrogen, phosphorus, potassium and chlorophyll content of papaya leaf.
Mycorrhiza, News, 16(2):15-16.

Sharma, H.G. (2004). Studies on blending impact of nutrients under different fertigation levels on growth, yield and quality of papaya (Carica papaya 1.). IGKVV, Raipur (C.G.), Ph.D. Thesis., pp 1-184.

Sharkey, T. D. and Ogawa, T. (1987). Stomatal responses to light in stomatel function, zinger, E.G.D. Farquhar and I.R. Cowan (Eds.). Stand Ford University Press, Stand (CA) USA, pp.195-227.

Tandel, B.M., Patel B.N. and Patel, B.B. (2014). Effect of Integrated Nutrient Management on Growth and Physiological Parameters on Papaya cv. Taiwan Red lady. Trends in Bioscience, 7(16): 2175-2178.

Tripathy, R.K. (2002). Influence of cow dung blended nutrients and agro-inputs on yield and nutrient use efficiency of hybrid rice (Oryza sativa L.) chickpea (Cicer arietinum L.) cropping system. Ph.D. Thesis, IGAU, Raipur (C.G.)

Yadav, P. K., Yadav, A. L., Yadav, A.S. and Yadav, H. C. (2011). Effect of integrated nutrient nourishment on vegetative growth and physico-chemical attributes of papaya (Carica papaya L.) fruit cv. Pusa Dwarf. Plant Archives, 11(1): 327329.

Yadav, P.K. (2006). Effect of integrated nutrient management on growth, yield and quality of papaya (Carica papaya L.) fruit. Ph.D. Thesis, Submitted to C.S.A. University of Agriculture and Technology, Kanpur, Uttar Pradesh, India.

\section{How to cite this article:}

Mahendra Jadia, S. S. Singh, S. P. Mishra, Krapal Singh Verma and Anil Kumar Patle. 2019. Effect of Inorganic and Biofertilizers on Growth of Gynodioecious Papaya. Int.J.Curr.Microbiol.App.Sci. 8(10): 1377-1385. doi: https://doi.org/10.20546/ijcmas.2019.810.161 